\title{
The Effect of Transcutaneous Electric Nerve Stimulation (TENS) on Anxiety and Fear in Children Aged 9-14 Years
}

\section{Utjecaj transkutane električne stimulacije živaca (TENS) na anksioznost i strah kod djece u dobi od 9 do 14 godina}

\author{
${ }^{1}$ Community Health Centre Zagreb-West, Postgraduate student, School of Dental Medicine, University of Zagreb, Croatia \\ Dom zdravlja Zagreb-zapad, studentica poslijediplomskog studija Stomatološkog fakulteta Sveučilišta u Zagrebu, Hrvatska \\ 2 Department of Paediatric and Preventive Dentistry, School of Dental Medicine, University of Zagreb, Croatia \\ Zavod za dječju i preventivnu stomatologiju Stomatološkog fakulteta Sveučilišta u Zagrebu, Hrvatska \\ ${ }^{3}$ Department of Neurology at Sestre milosrdnice Hospital, School of Dental Medicine, University of Zagreb, Croatia \\ Odjel za neurologiju bolnice Sestara milosrdnica - Stomatološki fakultet Sveučilišta u Zagrebu, Hrvatska
}

\section{Abstract}

Introduction: Dental fear or dental phobia is caused by previous unpleasant dental experiences and pain. It can result in delaying or avoiding dental visits. Most often it leads to individuals avoiding visiting the dentist until physical pain completely impairs the quality of life. Objectives: Transcutaneous electrical nerve stimulation (TENS) is a method of pain relief involving the use of a mild electrical current. The main aim of this study was to examine whether the TENS device affects the reduction of anxiety and fear during dental procedures. Material and Methods: The study was conducted on a sample of 125 respondents, aged 9-14 years. Statistical significance of differences between pre- and post-treatment results on all applied measuring instruments was verified by the t-test for dependent samples. The calculation was performed for all respondents and individually for the three observed groups. The Children`s Fear Survey Schedule - Dental Subscale test was used to assess anxiety and fear. Results: The results on the CFSS-DS scale in all subjects did not differ statistically significantly before and after treatment $(p>0.05)$. The results on the CFSS-DS scale in subjects who received TENS were statistically significantly different before and after treatment $(p<0.01)$. The results on the CFSSDS scale in subjects who received local anesthesia were statistically significantly different before and after treatment $(p<0.05)$. Conclusion: The TENS device had an anxiolytic effect after the first visit.
Received: July 29, 2020

Accepted: November 10, 2020

Address for correspondence Nina Cebalo Health Center Zagreb-West Prilaz baruna Filipovića 11, 10000 Zagreb, Croatia

ninacebalo@gmail.com

Key words

Children; Dental Anxiety; Transcutaneous Electric Nerve Stimulation; Pain Management

\section{Introduction}

Anxiety is a state of fear and dread all the way to panic, with psychomotor tension and inner restlessness. Dental anxiety is a narrower term and is caused by a specific stressful situation in the dental office setting. Fear most often arises due to traumatic childhood experiences or the adoption of phobic behavior by parents (1). Anxiety can be caused by the expectation of a dangerous situation in the perception of which cognitive processes are involved. According to a study of Bajrić and Juric there is no difference in the prevalence of dental anxiety/fear regarding age (2). One of the parameters that have great influence on these cognitive processes is fear of dental pain along with knowledge, feelings, and attitudes of the patient. There are two main types of dental fear: subjective and objective. Subjective dental fear is based on personal opinions and feelings rather than on facts. Objective dental fear is a reaction to a known danger because it occurs in people who have already had certain negative dental experiences; therefore, they expect it to necessarily recur. The most intense form of fear of the dentist is dental phobia (3). Anxious patients

\section{Uvod}

Anksioznost je stanje straha i straha sve do panike, sa psihomotornom napetošću i unutarnjim nemirom. Dentalna anksioznost uži je pojam i prouzročena je specifičnom stresnom situacijom u stomatološkoj ordinaciji. Strah se najčešce pojavljuje zbog traumatičnih iskustava u djetinjstvu ili usvajanja fobičnog ponašanja od roditelja (1). Anksioznost može nastati ako se očekuje opasna situacija u percepciji pri kojoj su uključeni kognitivni procesi. Prema istraživanju Bajrića i Jurića, nema razlike u prevalenciji zubne anksioznosti/straha s obzirom na dob (2). Jedan od parametara koji ima velik utjecaj na te kognitivne procese jest strah od bolova u zubima te znanja, osjećaji i stajališta pacijenta. Dvije su glavne vrste zubnoga straha - subjektivna i objektivna. Subjektivni zubni strah temelji se na osobnom mišljenju i osjećajima, a ne na činjenicama. Objektivni zubni strah reakcija je na poznatu opasnost jer se pojavljuje kod ljudi koji su već imali određena negativna stomatološka iskustva i očekuju da će se nužno ponoviti. Najintenzivniji oblik straha od stomatologa jest dentalna fobija (3). Uznemireni pacijent obično traži liječenje sa- 
tend to seek treatment only in the case of current pain caused by complications, thus emphasizing the anxiety condition in the office. The psychological characteristics of a person and potentially negative experience are stronger than the objective state related to the procedure itself. A circle of anxiety and pain is created, with a constant tendency to increase. Pain during dental procedures is associated, among other things, with the emotional state. Other factors that affect the experience of pain are age, gender, oral health, the frequency of visits to the dentist, socioeconomic status, and the way the patient is treated. Despite advances in dental procedures and pain control methods, most patients describe a visit to the dentist as a painful and uncomfortable experience $(4,5)$. After determining the cause of pain and anxiety, it is the dentist's task to find optimal pain control. This is achieved by a special psychological approach and anesthesia. Pain control depends on the recognition of psychological needs, knowledge, and skills necessary for the proper performance of the dental procedure and postoperative care of the patient. Transcutaneous electrical nerve stimulation (TENS) is a method of pain relief involving the use of a mild electrical current. Previous research has shown that the use of TENS reduces anxiety in the pediatric population; hence TENS is used effectively to suppress pain during various procedures, such as fissure sealing, minor extractions, and endodontic procedures (6). Since TENS is a non-invasive method, the assumption is that just one TENS device treatment will be enough to reduce the anxiety in the child. Clinical examination in children is a potentially stressful event as the child encounters a new situation that can be daunting. $\mathrm{He}$ encounters new smells, the sound of a drill, the water produced by it, the white coat of the dentist and many other factors that significantly affect the mental state of the child (79). Children may also experience fear of choking on water, fear of injections or needles, and fear of pain during dental procedures. At the first clinical examination, only the dental status is usually taken, and a minimally invasive procedure is performed for the child to relax and realize that no terrible or painful sensation will occur. For many years, behavioral methods have been developed that would relax the child during the dental procedure (10). Some of them are a "tell-show-do" method that explains to the child and shows what will happen during the procedure (11). This method gives the young child and preadolescent (age 3-12) a sense of control over the procedure and thus avoids the fear of unknown sounds and other factors that can scare the child (12). There are numerous ways of distracting the child such as listening to music during the procedure, watching cartoons, using tablets or large screens in the office, and using 2D or 3D glasses (13-15).

\section{Material and methods}

A TENS device is a battery-operated, small device that has leads connected to sticky pads called electrodes. The pads are attached directly to the person's skin. When the machine is switched on, small electrical impulses are delivered to the affected area of the body, which is felt as a tingling sensation. TENS is not a cure for pain and often provides only shortterm relief, while the TENS device is being used. The electri- mo u slučaju trenutačne boli prouzročene komplikacijama. To ističe anksioznost u ordinaciji. Psihološke osobine osobe i potencijalno negativno iskustvo jači su od objektivnog stanja vezanoga uz sam postupak. Iz tog razloga stvara se krug tjeskobe i boli, sa stalnom tendencijom povećanja. Bol tijekom stomatoloških zahvata povezana je, između ostaloga, s emocionalnim stanjem. Ostali čimbenici koji utječu na iskustvo boli su dob, spol, oralno zdravlje, učestalost posjeta stomatologu, socijalno-ekonomski status i način liječenja pacijenta. Unatoč napretku stomatoloških postupaka i metoda kontrole boli, većina pacijenata opisuje posjet stomatologu kao bolno i neugodno iskustvo $(4,5)$. Nakon utvrđivanja uzroka boli i anksioznosti, zadatak je stomatologa da pronade optimalnu kontrolu boli. To se postiže posebnim psihološkim pristupom i anestezijom. Kontrola boli ovisi o prepoznavanju psiholoških potreba, znanja i vještina potrebnih za pravilno obavljanje stomatološkog postupka i postoperativnu njegu pacijenta. Transkutana električna stimulacija živaca (TENS) metoda je za ublažavanje boli koja uključuje blagu električnu struju. U dosadašnjim istraživanjima autori su pokazali da upotreba TENS-a smanjuje anksioznost u dječjoj populaciji, pa se taj postupak učinkovito koristi za suzbijanje boli tijekom različitih postupaka poput brtvljenja fisura, manjih vađenja i endodontskih postupaka (6). Budući da je TENS neinvazivna metoda, pretpostavka je da će samo jedan tretman biti dovoljan da smanji tjeskobu kod djeteta. Klinički pregled djece potencijalno je stresan događaj jer se dijete susreće s novom situacijom koja može biti zastrašujuća. Susreće se s novim mirisima, zvukom bušilice, vodom koju ona proizvodi, bijelom odorom stomatologa i mnogim drugim čimbenicima koji znatno utječu na njegovo mentalno stanje $(7-9)$. Djeca se također mogu bojati gušenja vodom, injekcije ili igle te boli tijekom stomatoloških zahvata. Na prvom kliničkom pregledu obično se uzima samo zubni status, a obavlja se samo neki minimalno invazivni postupak kako bi se dijete opustilo i shvatilo da se neće pojaviti strašni ili bolni osjeti. Već se godinama razvijaju metode ponašanja koje bi opuštale dijete tijekom stomatološkog zahvata (10). Među njima je tell-show-do metoda kada se djetetu objašnjava i pokazuje što će se dogoditi tijekom postupka (11). Ta metoda potiče u malom djetetu i predadolescentu (3 - 12 godina) osjećaj kontrole nad postupkom pa se na taj način izbjegava strah od nepoznatih zvukova i drugih čimbenika koji dijete mogu prestrašiti (12). Mnogobrojni su načini odvraćanja djeteta - od slušanja glazbe tijekom postupka, gledanja crtića, upotrebe tableta ili velikih ekrana u ordinaciji i korištenja 2D ili 3D naočala $(13-15)$.

\section{Materijali i metode}

TENS je mali uređaj na baterije koji ima elektrode povezane s ljepljivim jastučićima zvanima elektrode. Jastučići se pričvršćuju izravno na kožu. Kad se stroj uključi, na zahvaćeno područje tijela dostavljaju se lagani električni impulsi, što se osjeća kao trnci. TENS nije lijek protiv boli i često pruža samo kratkotrajno olakšanje dok se koristi. Električni impulsi mogu smanjiti signale boli koji idu prema leđnoj moždini i 
cal impulses can reduce the pain signals going to the spinal cord and brain, which may help relieve pain and relax muscles. They may also stimulate the production of endorphins, which are the body's natural painkillers (16). The subjects were included in the study based on the established dental diagnosis of anxiety and selection of patients in need of restorative procedure on a permanent molar. Subsequently, they were randomly grouped into three groups at the first visit to the dentist: 1) Group A, including 41 children, with no anesthesia; 2) Group B, including 42 children on whose skin of the face the TENS device was applied; 3) Group C, including 42 children who underwent classical local anesthesia. The research was conducted by one therapist who was calibrated. In the waiting room, the patient's parents received information forms, which they ultimately signed, on which it was written that all information collected during the study will be obtained with the informed consent of the patient, and they are strictly confidential. The identity of the research participant is known to the dentist conducting the research and to the institution for which the responsible doctor conducts the research. The children received instructions on how to complete the "STRESS TEST" immediately before the examination, informative interview, and dental procedure (class I filling on a permanent molar in the upper or lower jaw). Children were randomly divided one to each group. All the cavities had similar dimensions and depth. Children in all groups suffered low to mild pain (the local anesthesia group reported mild pain from the needle) which was the potential stressor and the cause of anxiety. The stress test validated in the Republic of Croatia was used: CFSS-DS (Children's Fear Survey Schedule - Dental Subscale) (17). This test consists of 15 particles in which the level of fear is measured on a scale from 1 to $5(1=$ not afraid at all to $5=$ very afraid). The range of points is from 15 75 , and the intensity of the patient's fear is proportional to the number of points. The overall score of the scale (either as a sum or as the average value of points on individual issues) indicates a degree of anxiety - a higher score indicates a higher degree of anxiety. The Cronbach's alpha was 0.86 . The respondents were regular patients of the Department of Pediatric and Preventive Dentistry at the School of Dental Medicine in Zagreb. The study was approved by the Ethics Committee of the School of Dental Medicine University of Zagreb. For the results obtained by the research, basic indicators of descriptive statistics (arithmetic mean, standard deviation, Pearson's asymmetry coefficient) were calculated. Statistical significance of differences between pre- and post-treatment results on all applied measuring instruments was verified by t-test for dependent samples. To further determine the interrelationship of the observed variables, a complex (two-factor) analysis of variance was performed.

\section{Results}

With a sample size of $\mathrm{N}=125$ and a risk level of 5\%, Power analysis of the test determined a test power of 0.78 , which satisfies the generally accepted conditions. The study included 85 girls (68\%) and 40 boys (32\%) treated over a two-year period (Figure 1). The arithmetic mean of age of mozgu, što može pomoći u ublažavanju boli i opuštanju mišića. Oni također mogu stimulirati proizvodnju endorfina koji djeluje kao prirodna tableta protiv bolova u organizmu (16). Ispitanici su bili uključeni u istraživanje na temelju utvrđene dentalne dijagnoze anksioznosti i odabira pacijenata kojima je bio potreban restaurativni zahvat na trajnom kutnjaku i nasumično su grupirani u tri skupine pri prvom posjetu stomatologu: 1) skupina A - 41 dijete, bez anestezije; 2) skupina $B-42$ djeteta na čiju je kožu lica postavljen uređaj TENS; 3) skupina $\mathrm{C}$ - također 42 djeteta koja su bila podvrgnuta klasičnoj injekciji u lokalnoj anesteziji. Istraživanje je proveo jedan baždareni terapeut. U čekaonici su roditelji pacijenta potpisali formulare o pristanku da njihova djeca sudjeluju u studiji, s time da je istaknuto kako su svi podatci prikupljeni tijekom studije strogo povjerljivi. Identitet sudionika istraživanja bio bi poznat stomatologu koji provodi istraživanje i instituciji za koju odgovorni liječnik obavlja istraživanje. Djeca su dobila upute kako obaviti TEST STRESNOSTI neposredno prije pregleda, informativnog razgovora i stomatološkog postupka (ispun I. klase na trajnom kutnjaku u gornjoj ili donjoj čeljusti). Djeca su nasumce podijeljena po jedno u svaku skupinu. Sve zubne šupljine imale su slične dimenzije i dubinu. Djeca u svim skupinama osjetila su slabu do blagu bol (skupina s lokalnom anestezijom prijavila je blagu bol od igle) koja je bila potencijalni stresor i uzrok anksioznosti. Korišten je test otpornosti na stres potvrđen u Republici Hrvatskoj: CFSS-DS (Dječji program ispitivanja straha - zubna subskala) (17). Taj se test sastoji od 15 čestica u kojima se razina straha mjeri na ljestvici od 1 do 5 ( 1 = nimalo se ne boji do 5 = jako se boji). Raspon bodova je od 15 do 75 , a intenzitet pacijentova straha proporcionalan je broju bodova. Ukupna ocjena ljestvice (ili kao zbroj ili kao prosječna vrijednost bodova za pojedina pitanja) upućuje na stupanj anksioznosti viši rezultat označava veći stupanj anksioznosti. Cronbachova alfa iznosi 0,86. Ispitanici su bili redoviti pacijenti Zavoda za dječju i preventivnu stomatologiju Stomatološkog fakulteta u Zagrebu. Studiju je odobrilo Etičko povjerenstvo Stomatološkog fakulteta Sveučilišta u Zagrebu. Za rezultate dobivene istraživanjem izračunati su osnovni pokazatelji deskriptivne statistike (aritmetička sredina, standardna devijacija, Pearsonov koeficijent asimetrije). Statističke značajnosti razlika između rezultata prije tretmana i poslije njega na svim primijenjenim mjernim instrumentima provjerene su t-testom za zavisne uzorke. Radi dodatnog utvrđivanja međuodnosa promatranih varijabli provedena je složena (dvofaktorska) analiza varijance.

\section{Rezultati}

Uz veličinu uzorka $\mathrm{N}=125$ i razinu rizika od $5 \%$ Powerom analizom, utvrđena je snaga testa u iznosu od 0,78 , što zadovoljava općeprihvaćene uvjete. U studiju je bilo uključeno 85 djevojčica (68\%) i 40 dječaka (32\%) liječenih tijekom dvogodišnjeg razdoblja. Aritmetička srednja (prosječna) dob 
the patients was 11.53 years (range 9-14 years), with a standard deviation of 1.78 years and a Pearson asymmetry coefficient $(\alpha)$ of 0.03 (results were evenly distributed around the arithmetic mean) (Table 1: Figure 2). Statistical significance of differences between pre- and post-treatment results on all applied measuring instruments was verified by $\mathrm{t}$-test bolesnika bila je 11,53 godine (raspon od 9 do 14 godina), sa standardnom devijacijom od 1,78 godina i Pearsonovim koeficijentom asimetrije $(\alpha)$ 0,03 (rezultati su ravnomjerno raspoređeni oko aritmetičke srednje vrijednosti). Statističke značajnosti razlika između rezultata prije tretmana i poslije njega na svim primijenjenim mjernim instrumentima pro-

Table 1 Statistical indicators of the age of the respondents

Tablica 1. Statistički pokazatelji dobi ispitanika

\begin{tabular}{|c|c|c|c|c|c|c|}
\hline \multicolumn{5}{|c|}{ AGE } & SD & $\boldsymbol{\alpha}$ \\
\hline N & MIN & MAX & M & 1,78 & 0,03 \\
\hline
\end{tabular}

MIN - Minimum; MAX - Maximum; M- Arithmetic mean (average); SD - Standard deviation; $\alpha$ - Pearson's asymmetry coefficient •

Table 2 Results of t-test for dependent samples of CFSS-DS (before and after treatment)

Tablica 2. Rezultati t-testa za ovisne uzorke CFSS-DS (prije tretmana i poslije njega)

\begin{tabular}{|c|c|c|c|c|c|c|}
\hline \multicolumn{7}{|c|}{ t-test CFSS-DS } \\
\hline \multirow[b]{2}{*}{ Group } & \multirow[b]{2}{*}{$\mathbf{N}$} & \multicolumn{2}{|c|}{ Before treatmant } & \multicolumn{2}{|c|}{ After treatmant } & \multirow{2}{*}{ p-value } \\
\hline & & $\mathbf{M}$ & SD & $\mathbf{M}$ & SD & \\
\hline All respondents & 125 & 2,28 & 0,80 & 2,34 & 1,09 & 0,5127 \\
\hline Tens & 42 & 2,64 & 0,79 & 1,82 & 0,56 & $0,0000^{* *}$ \\
\hline Local anesthesia & 42 & 2,18 & 0,78 & 2,54 & 1,22 & $0,0159^{*}$ \\
\hline Without anesthesia & 41 & 2,02 & 0,72 & 2,67 & 1,17 & $0,0000^{* *}$ \\
\hline
\end{tabular}

\section{Structure of respondents by gender} $(\mathrm{N}=125)$

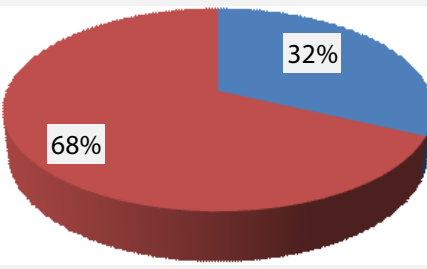

\section{Distribution of respondents by age $(\mathrm{N}=125)$}

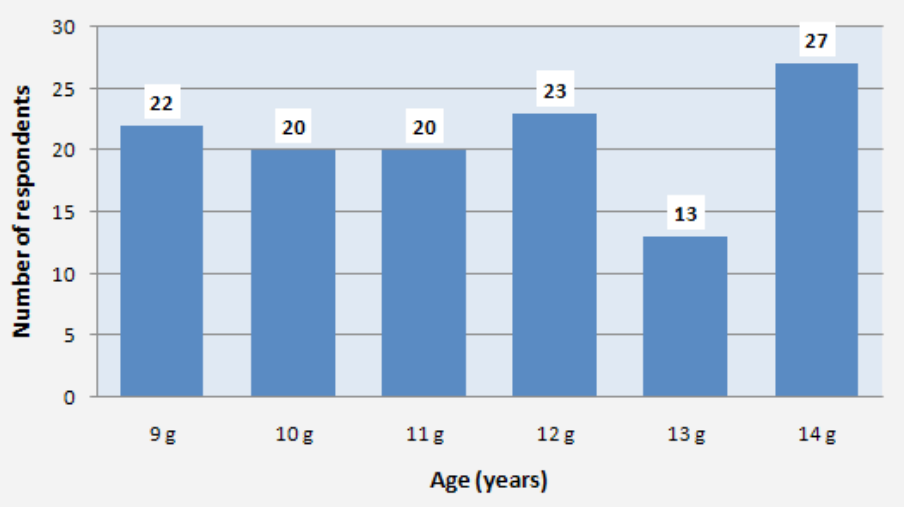

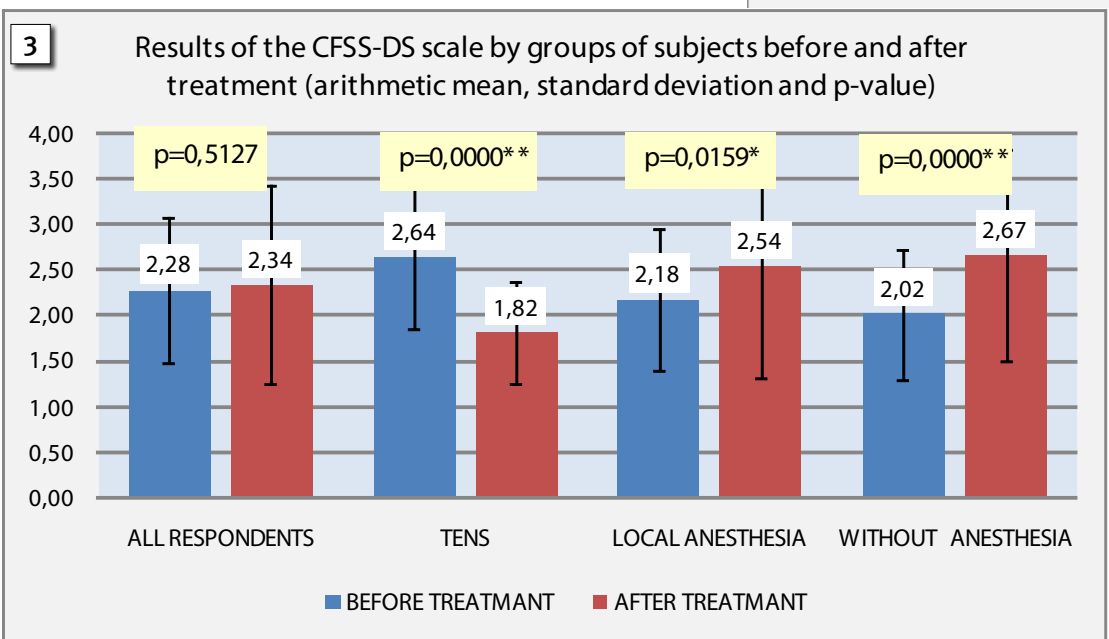

Figure 1 Structure of all respondents by gender

Slika 1. Struktura svih ispitanika prema spolu

Figure 2 Distribution of all respondents by age

Slika 2. Raspodjela svih ispitanika prema dobi

Figure 3 Arithmetic means, standard deviations, and $p$-values of the t-test of the CFSS-DS scale before and after treatment

Slika 3. Aritmetičke sredine, standardna odstupanja i p-vrijednosti t-testa CFSS-DS ljestvice prije tretmana i poslije njega 
for dependent samples. The calculation was performed for all respondents and individually for the three observed groups (Table 2: Figure 3). Results on the CFSS-DS scale in all subjects did not differ statistically significantly before and after treatment $(p>0.05)$. Results on the CFSS-DS scale in subjects who received TENS were statistically significantly different before and after treatment $(\mathrm{p}<0.01)$. Results on the CFSS-DS scale in subjects who received local anesthesia were statistically significantly different before and after treatment $(p<0.05)$. Lower results were achieved by subjects before treatment. Results on the CFSS-DS scale in subjects who did not receive any anesthesia were statistically significantly different before and after treatment $(\mathrm{p}<0.01)$. Lower results were achieved by subjects before treatment. In order to further investigate the influence of two factors (measurement time "before treatment" and "after treatment") and method of anesthesia ("TENS", "local anesthesia" and "without any anesthesia")) on the results in the scales used in the study we are a complex (two-factor) analysis of variance. The results indicate the following:

1. There is no statistically significant influence $(p>0.05)$ of the method of anesthesia on the results in the CFSS-DS scale (neglecting time factor (before - after treatment)).

2. There is no statistically significant effect $(p>0.05)$ of measurement time (before / after) on the results in the CFSS-DS scale (neglecting the method of anesthesia).

3. There is a statistically significant interaction $(p<0.01)$ between the measurement time and the method of anesthesia in influencing the results in the CFSS-DS scale.

\section{Discussion}

It is thought that when a patient shows only mild anxiety, it can be alleviated by developing a relationship based on trust and by giving detailed information about the procedure to be performed, so that the patient has a sense of control over what happens in the office $(5,6,18)$. In patients who feel higher anxiety, it is possible to alleviate it with some of the pharmacological (Nitrous oxide (19), oral sedation and drugs $(20,21)$ ) and non-pharmacological (distraction (7-8), listening to music $(22,23)$, breathing exercises $(24,25)$, hypnosis $(26,27))$ methods. In a randomized controlled trial, Kritsidima, Newton and Asimakopoulou found that dental patients exposed to the scent of lavender, while waiting in the waiting room, show less anxiety compared to control group (28). This research is consistent with the results of previous research where the scent of lavender or orange was used in waiting rooms (29-31). In more recent times, virtual reality has also been used by wearing 3D glasses $(14,15)$. Giving the patient a way to communicate with the dentist during the procedure (to which the dentist responds) increases the patient's sense of control and trust. Specific signals can be determined ahead of time, e.g. raising a hand means stopping. When performing the procedure, it is also advisable to take short breaks for the child to calm down and rest from keeping his mouth open. Positive reinforcement in terms of small tangible rewards or verbal recognition could provide a useful collaboration or appropriate behavior $(9,11)$. This method, vjerene su t-testom za zavisne uzorke. Izračun je obavljen za sve ispitanike te pojedinačno u tri promatrane grupe. Rezultati su prikazani u tablicama xyz - xyt i grafickkim prikazima vfd - hzt. Rezultati na ljestvici CFSS-DS na svim ispitanicima statistički se ne razlikuju značajno prije tretmana i poslije njega $(\mathrm{p}>0,05)$. Rezultati na ljestvici CFSS-DS za ispitanike na kojima je primijenjen TENS, statistički se značajno razlikuju prije tretmana i poslije njega $(\mathrm{p}<0,01)$. Niže rezultate postigli su ispitanici poslije tretmana. Rezultati na ljestvici CFSS-DS za ispitanike na kojima je primijenjena lokalna anestezija, statistički se značajno razlikuju prije tretmana i poslije njega $(p<0,05)$. Niže rezultate postigli su ispitanici prije tretmana. Rezultati na ljestvici CFSS-DS za ispitanike na kojima nije primijenjena nikakva anestezija, statistički se značajno razlikuju prije tretmana i poslije njega $(\mathrm{p}<, 01)$. Niže rezultate postigli su ispitanici prije tretmana. Kako bi se dodatno istražio utjecaj dvaju čimbenika - vrijeme mjerenja (prije tretmana i poslije tretmana) i način anestezije (TENS, lokalna anestezija i bez ikakve anestezije) na rezultate u ljestvicama korištenima u istraživanju primijenili smo složenu (dvofaktorsku) analizu varijance. Rezultati upućuju na sljedeće: ne postoji statistički značajan utjecaj $(\mathrm{p}>0,05)$ načina anestezije na rezultate u ljestvici CFSS-DS [zanemarujući čimbenik vremena (prije - poslije tretmana)]. Ne postoji statistički značajan utjecaj $(p>0,05)$ vremena mjerenja (prije/poslije) na rezultate u ljestvici CFSS-DS (zanemarujući način anestezije). Postoji statistički značajna interakcija $(\mathrm{p}<0,01)$ između vremena mjerenja i načina anestezije pri utjecaju na rezultate u ljestvici CFSS-DS.

\section{Rasprava}

Smatra se da ako pacijent pokazuje samo blagu anksioznost, to se može ublažiti postizanjem odnosa temeljenog na povjerenju i davanjem detaljnih informacija o postupku koji slijedi tako da pacijent ima osjećaj kontrole nad onim što se događa u ordinaciji $(5,6,18)$. Kod bolesnika koji osjećaju veću anksioznost ona se može ublažiti nekim farmakološkim sredstvom [dušikov oksid (19), oralna sedacija i lijekovi (20, 21)] te nefarmakološkima [distrakcija (7 - 8), slušanje glazbe $(22,23)$, vježbe disanja $(24,25)$, hipnoza $(26,27)]$. Kritsidima, Newton i Asimakopoulou otkrili su u randomiziranom kontroliranom ispitivanju da stomatološki pacijenti izloženi mirisu lavande dok čekaju u čekaonici pokazuju manju anksioznost u odnosu prema kontrolnoj skupini (28). To je istraživanje u skladu s rezultatima dosadašnjih istraživanja gdje se u čekaonicama koristio miris lavande ili naranče $(29-31)$. U novije se doba koristi i virtualna stvarnost nošenjem $3 \mathrm{D}$ naočala $(14,15)$. Interakcija sa stomatologom tijekom postupka (na što stomatolog reagira) povećava pacijentov osjećaj kontrole i povjerenja. Određeni signali mogu se utvrditi prije obrade zuba, npr. dizanje ruke znači zaustavljanje. Pri obavljanju postupka također su poželjne kratke stanke kako bi se dijete smirilo i odmorilo od držanja usta otvorenima. Pozitivno pojačanje u smislu malih opipljivih nagrada ili verbalnog prepoznavanja moglo bi potaknuti korisnu suradnju ili odgovarajuće ponašanje $(9,11)$. Ta se metoda smatra univerzalno prihvaćenom tehnikom upravljanja ponašanjem u pružanju 
and particularly positive feedback, is considered a universally accepted behavioral management technique in providing dental care to children and is based on psychological principles that have been shown to be effective over a longer time period (32). An exercise believed to be beneficial to almost every timid patient is relaxation through breathing exercises. The physiological changes that accompany breathing (relaxed or diaphragmatic) effectively create the opposite effect to the struggle or flight reaction that characterizes anxious individuals $(24,25)$. There are several ways to achieve relaxation through breathing. Milgrom et al. describe a procedure in which patients learn to inhale slowly and deeply and hold each breath for approximately 5 seconds, before exhaling slowly (33). Slow, continuous breathing for 2 to 4 minutes is considered effective in reducing the patient's heart rate and makes the anxious patient noticeably calmer. In his research, Ackley advised that patients should be asked to breathe so slowly that if a feather was to be under their nose, it wouldn 't move (34). These breathing techniques can be taught at a dental clinic, or the patient can apply them at home before the initial examination. Physiological monitoring of respiration through a heart rate monitor or other biofeedback device can be beneficial to both the patient and the dentist and has been shown to be effective in reducing dental anxiety and negative emotions about dental injections (35). In working with children, it is important to find out, through conversation and with a lot of patience, which type of distraction makes them happy and which technique will most successfully distract attention from the procedure to be performed. Performing a dental procedure should certainly be a positive experience so that children continue to come to further procedures with pleasure and without fear. In 2014, a study about waiting rooms showed in a relatively high percentage that equipping waiting rooms with toys or allowing a child to hold a toy during the procedure is a way to distract difficult or anxious children (36). Other studies have shown the benefits of using distractions, where access to a distractor, such as a personal music player, depends on collaborative behavior (37). The use of the TENS device as a distractor is an innovative method used to relieve anxiety in frightened children.

A study of usage of TENS in dentistry is limited to minimally invasive clinical procedures where a low level of pain is expected. It is not recommended for surgical procedures, extensive and deep restorations, or extractions. Limitations of this study were different emotional development stages in children due to different ages of study participants. Respondents' level of pain perception was also variable.

\section{Conclusions}

In this study, the TENS device proved to be a successful distraction method. The results showed that the group on which the TENS device was applied felt less anxiety after the procedure, unlike the groups with and without local anesthesia where patients felt more anxiety after the procedure. The TENS device used during the entire procedure served to distract the subjects from the procedure itself, as well as the feelings of some of the sensations which occurred during it. Since stomatološke skrbi djeci i temelji se na psihološkim načelima koja su se pokazala učinkovitima tijekom duljeg razdoblja (32). Vježba za koju se vjeruje da je korisna za gotovo svakog plašljivog pacijenta jest opuštanje na temelju vježbe disanja. Fiziološke promjene koje prate disanje (opušteno ili dijafragmatično) učinkovito stvaraju suprotan učinak reakciji borbe ili bijega koji karakteriziraju tjeskobne osobe $(24,25)$. Postoji nekoliko načina opuštajućeg disanja. Milgrom i suradnici opisali su postupak u kojemu pacijenti nauče polako i duboko udahnuti te zadržati svaki dah otprilike pet sekunda prije nego što polako izdahnu (33). Polako, kontinuirano disanje od dvije do četiri minute smatra se učinkovitim u smanjenju pacijentovih otkucaja srca te tjeskobnoga pacijenta čini primjetno mirnijim. Ackley je u svojem istraživanju savjetovao da se od pacijenata traži da polako dišu kako im se pero stavljeno ispod nosa ne bi pomaknulo (34). Tim se tehnikama disanja može podučavati u stomatološkoj ordinaciji ili ih pacijent može primijeniti kod kuće prije prvog pregleda. Fiziološko praćenje disanja na monitoru za otkucaje srca ili na nekom drugom uređaju za biofeedback može biti korisno i za pacijenta i za stomatologa, a pokazalo se učinkovitim u smanjenju zubne anksioznosti i negativnih emocija zbog injekcija (35). U radu s djetetom važno je u razgovoru, i s mnogo strpljenja, doznati koja vrsta distrakcije ga najviše raduje i koja bi najuspješnije odvratila pozornost od postupka koji treba učiniti. Stomatološki postupak svakako bi trebao biti pozitivno iskustvo, tako da dijete i dalje dolazi na zahvate sa zadovoljstvom i bez straha. Studija o čekaonicama iz 2014. godine pokazala je u razmjerno visokom postotku da je njihovo opremanje igračkama ili omogućavanje djetetu da tijekom postupka drži igračku, način odvraćanja pozornosti teške ili tjeskobne djece (36). U drugim je studijama istaknuta prednost korištenja distrakcija, pri čemu pristup distrakterima, kao što je na primjer osobni svirač glazbe, ovisi o suradničkom ponašanju (37). Korištenje TENS uređaja kao distraktora inovativna je metoda kojom se pokušava prevladati tjeskoba kod prestrašene djece. Proučavanje njegove primjene u stomatologiji ograničeno je na minimalno invazivne kliničke postupke kada se očekuje niska razina boli. Ne preporučuje se za kirurške zahvate te opsežne i duboke restauracije ili vađenja. Ograničenja studije bili su različiti stadiji emocionalnog razvoja kod djece zbog različite dobi sudionika. Percepcija razine boli kod sudionika također je bila promjenjiva.

\section{Zaključak}

U ovoj se studiji uređaj TENS pokazao uspješnom distrakcijskom metodom. Rezultati su pokazali da je skupina, na kojoj je primijenjen taj uređaj, osjećala manje anksioznosti nakon zahvata, za razliku od skupina s lokalnom anestezijom i bez nje, kada su pacijenti osjećali veću anksioznost nakon zahvata. Uređaj TENS, korišten tijekom cijelog postupka, služio je za odvraćanje ispitanika od samog postupka, kao i od nekih osjeta koji se tijekom njega pojavljuju. Budući 
each child had a different pain tolerance threshold, the same amount of electricity could not be given equally to all subjects, and for this reason the control of the current given to each subject individually was optional. The children were focused on the tingling caused by mild administration of electricity and on dosing it to make their treatment more comfortable and less painful. The TENS device also served as a kind of "toy" for the child to have fun during the procedure.

\section{Conflict of interests}

The authors declare no conflict of interest.

\section{Patient consent}

Written consent was obtained by parents.

\section{Author's contribution}

N.C. - Devised the idea of the research; Organized and conducted clinical research at the Department of Paediatric and Preventive Dentistry; Sublimated theories of electrical nerve stimulation and anxiety and fears in children; D.V.V. Contributed to the organization of the clinical part of the research at the Department of Paediatric and Preventive Dentistry, Croatia Moderated research, Supervised statistical data processing; V.B.K. - Contributed by insight into the theory of the mechanism of action of electrical nerve stimulation, Donated the TENS device da svako dijete ima drukčiji prag tolerancije boli, jednaka količina električne energije ne može se podjednako davati svim ispitanicima, pa je zbog toga kontrola struje koja se daje svakom ispitaniku neobvezna. Djeca su se usredotočila na trnce prouzročene blagim djelovanjem električne energije i na doziranje kako bi im tretman bio ugodan, a ne bolan. TENS uređaj poslužio je i kao svojevrsna igračka kojom se dijete tijekom postupka zabavljalo.

\section{Sukob interesa}

Autori nisu buli u sukobu interesa.

\section{Suglasnost}

Pismeno dopuštenje dali su roditelji djece.

\section{Doprinosi autora}

N. C. - osmislila ideju istraživanja, organizirala i obavila kliničko istraživanje u Zavodu za dječju i preventivnu stomatologiju Stomatološkog fakulteta Sveučilišta u Zagrebu, Hrvatska, sublimirala teorije električne stimulacije živaca te anksioznosti i strahova kod djece; D. N . V. - pridonijela organizacijom kliničkog dijela istraživanja u Zavodu za dječju i preventivnu stomatologiju, moderirala istraživanje, nadzirala statističku obradu podataka; V. B. K. - pridonijela uvidom u teoriju mehanizma djelovanja električne stimulacije živaca, donirala TENS uređaj.

\section{Sažetak}

Zubni strah ili zubna fobija rezultat je neugodnog iskustva i boli zbog kojih odgađamo ili izbjegavamo posjet stomatologu. Najčešće to završava tako da pojedinci izbjegavaju odlazak stomatologu dok bol potpuno ne naruši kvalitetu života. Cilj: Transkutana električna stimulacija živaca (TENS) metoda je za ublažavanje boli koja uključuje blagu električnu struju. Glavni cilj ove studije bio je ispitati utječe li uređaj TENS na smanjenje tjeskobe i straha tijekom stomatoloških zahvata. Materijal i metode: Istraživanje je provedeno na uzorku od 125 ispitanika u dobi od 9 do 14 godina. Statistička značajnost razlika između rezultata prije tretmana i nakon njega na svim primijenjenim mjernim instrumentima potvrđena je t-testom za ovisne uzorke. Izračun je učinjen za sve ispitanike i pojedinačno za tri promatrane skupine. Za procjenu anksioznosti i straha korišten je dječji program ankete o strahu CFSS-DS (Dječji program za ispitivanje straha - zubna subskala). Rezultati: Rezultati na CFSS-DS ljestvici za sve ispitanike nisu se statistički značajno razlikovali prije tretmana i nakon njega $(p>0,05)$. Rezultati na CFSS-DS ljestvici za ispitanike koji su primili TENS statistički su se značajno razlikovali prije liječenja i poslije njega $(p<0,01)$. Rezultati na CFSS-DS ljestvici za ispitanike koji su primili lokalnu anesteziju statistički su se značajno razlikovali prije liječenja i poslije njega $(p<0,05)$. Zaključak: Uređaj TENS imao je anksiolitički učinak nakon prvog posjeta.
Zaprimljen: 29. srpnja 2020. Prihvaćen: 10. studenoga 2020.

Adresa za dopisivanje Nina Cebalo

Dom zdravlja Zagreb-zapad Prilaz baruna Filipovića 11, 10000 Zagreb, Hrvatska ninacebalo@gmail.com

Ključne riječi

djeca; tjeskoba od zubara; transkutana električna stimulacija živca; upravljanje bolovima

\section{References}

1. Nuvvula S, Alahari S, Kamatham R, Challa RR. Effect of audiovisual distraction with $3 \mathrm{D}$ video glasses on dental anxiety of children experiencing administration of local analgesia: a randomized clinical trial. Eur Arch Paediatr Dent. 2015 Feb;16(1):43-50.

2. Bajrić E, Jurić H. Prevalencija i čimbenici rizika za nastanak dentalnog straha i anksioznosti kod djece. Paediatria Croatica. 2011;55(3).

3. Asl AN, Shokravi M, Jamali Z, Shirazi S. Barriers and Drawbacks of the Assessment of Dental Fear, Dental Anxiety and Dental Phobia in Children: A Critical Literature Review. J Clin Pediatr Dent. 2017;41(6):399-423.

4. Appukuttan DP. Strategies to manage patients with dental anxiety and dental phobia: literature review. Clin Cosmet Investig Dent. 2016 Mar 10;8:35-50.

5. Heyman RE, Slep AM, White-Ajmani M, Bulling L, Zickgraf HF, Franklin $M E$ et al. Dental Fear and Avoidance in Treatment Seekers at a Large, Urban Dental Clinic. Oral Health Prev Dent. 2016;14(4):315-20.
6. Kasat V, Gupta A, Ladda R, Kathariya M, Saluja H, Farooqui AA. Transcutaneous electric nerve stimulation (TENS) in dentistry- $A$ review. J Clin Exp Dent. 2014 Dec 1;6(5):562-8.

7. Lin C-S, Wu S-Y, Yi C-A. Association between Anxiety and Pain in Dental Treatment: A Systematic Review and Meta-analysis. J Dent Res. 2017 Feb;96(2):153-162.

8. Goettems ML, Zborowski EJ, Costa FD, Costa VP, Torriani DD. Nonpharmacologic Intervention on the Prevention of Pain and Anxiety During Pediatric Dental Care: A Systematic Review. Acad Pediatr. 2017 Mar;17(2):110-9.

9. Seligman LD, Hovey JD, Chacon K, Ollendick TH. Dental anxiety: An understudied problem in youth. Clin Psychol Rev. 2017 Jul;55:25-40.

10. Armfield JM, Heaton LJ. Management of fear and anxiety in the dental clinic: a review. Aust Dent J. 2013 Dec;58(4):390-407; quiz 531.

11. Khandelwal D, Kalra N, Tyagi R, Khatri A, Gupta K. Control of Anxiety in Pediatric Patients using "Tell Show Do" Method and Audio- 
visual Distraction. J Contemp Dent Pract. 2018 Sep 1;19(9):105864.

12. Desai SH, Shah PP, Jajoo SS, Smita PS. Assessment of parental attitude toward different behavior management techniques used in pediatric dentistry. J Indian Soc Pedod Prev Dent. 2019 OctDec;37(4):350-9.

13. Sheshukova OV, Polishchuk TV, Kostenko VG, Trufanova VP, Bauman SS, Davydenko VY. Consideration of childhood psychological factors at dental appointment. Wiad Lek. 2018;71(7):1305-9.

14. Custódio NB, Costa FDS, Cademartori MG, da Costa VPP, Goettems ML. Effectiveness of Virtual Reality Glasses as a Distraction for Children During Dental Care. Pediatr Dent. 2020 Mar 15:42(2):93-102.

15. Bentsen B, Svensson P, Wenzel A. Evaluation of effect of $3 D$ video glasses on perceived pain and unpleasantness induced by restorative dental treatment. Eur J Pain. 2001;5(4):373-8.

16. Han JS. Acupuncture: neuropeptide release produced by electrical stimulation of different frequencies. Trends Neurosci. 2003 Jan;26(1):17-22.

17. Leko J, Škrinjarić T, Goršeta K. Reliability and Validity of Scales for Assessing Child Dental Fear and Anxiety. Acta Stomatol Croat. 2020 Mar;54(1):22-31.

18. Klingberg G, Broberg AG. Dental fear/anxiety and dental behaviour management problems in children and adolescents: a review of prevalence and concomitant psychological factors. Int J Paediatr Dent. 2007 Nov;17(6):391-406.

19. Galeotti A, Garret Bernardin A, D'Antò V, Ferrazzano GF, Gentile $\mathrm{T}$, Viarani $\mathrm{V}$ et al. Inhalation Conscious Sedation with $\mathrm{Ni}$ trous Oxide and Oxygen as Alternative to General Anesthesia in Precooperative, Fearful, and Disabled Pediatric Dental Patients: A Large Survey on 688 Working Sessions. Biomed Res Int. 2016;2016:7289310.

20. Ashley PF, Chaudhary M, Lourenço-Matharu L. Sedation of children undergoing dental treatment. Cochrane Database Syst Rev. 2018 Dec 17;12(12):CD003877.

21. Sebastiani FR, Dym H, Wolf J. Oral Sedation in the Dental Office. Dent Clin North Am. 2016 Apr;60(2):295-307.

22. Bradt J, Teague A. Music interventions for dental anxiety. Oral Dis. 2018 Apr;24(3):300-6.

23. Ainscough SL, Windsor L, Tahmassebi JF. A review of the effect of music on dental anxiety in children. Eur Arch Paediatr Dent. 2019 Feb;20(1):23-6.

24. Jerath R, Crawford MW, Barnes VA, Harden K. Self-regulation of breathing as a primary treatment for anxiety. Appl Psychophysiol Biofeedback. 2015 Jun;40(2):107-15.
25. Chen YF, Huang XY, Chien CH, Cheng JF. The Effectiveness of Diaphragmatic Breathing Relaxation Training for Reducing Anxiety. Perspect Psychiatr Care. 2017 Oct;53(4):329-36.

26. Al-Harasi S, Ashley PF, Moles DR, Parekh S, Walters V. WITHDRAWN: Hypnosis for children undergoing dental treatment. Cochrane Database Syst Rev. 2017 Jun 20;6(6):CD007154.

27. Wolf TG, Wolf D, Callaway A, Below D, d'Hoedt B, Willershausen B, et al. Hypnosis and Local Anesthesia for Dental Pain Relief-Alternative or Adjunct Therapy? - A Randomized, Clinical-Experimental Crossover Study. Int J Clin Exp Hypn. 2016 Oct-Dec;64(4):391-403.

28. Kritsidima M, Newton T, Asimakopoulou K. The effects of lavender scent on dental patient anxiety levels: a cluster randomised controlled trial. Community Dent Oral Epidemiol. 2010;38(1):83-

29. Arslan I, Aydinoglu S, Karan NB. Can lavender oil inhalation help to overcome dental anxiety and pain in children? A randomized clinical trial. Eur J Pediatr. 2020 Jun;179(6):985-92.

30. Karan NB. Influence of lavender oil inhalation on vital signs and anxiety: A randomized clinical trial. Physiol Behav. 2019 Nov 1;211:112676

31. Premkumar KS, Syed A, Sumalatha S, Narendran N. Effect of Aromatherapy on Dental Anxiety Among Orthodontic Patients: A Randomized Controlled Trial. Cureus. 2019 Aug 2;11(8):5306.

32. Slocum SK, Vollmer TR. A comparison of positive and negative reinforcement for compliance to treat problem behavior maintained by escape. J Appl Behav Anal. 2015 Sep;48(3):563-74.

33. Milgrom $P$, Weinstein $P$, Heaton $L$ - editors. Treating fearful dental patients: a patient management handbook. 3rd ed. Seattle, WA: Dental Behavioral Resources; 2009.

34. Ackley DC. Dental fear. Aren't you tired of it? Dent Today. 2003;22:96-102.

35. Morarend QA, Spector ML, Dawson DV, Clark SH, Holmes DC. The use of a respiratory rate biofeedback device to reduce dental anxiety: an exploratory investigation. Appl Psychophysiol Biofeedback. 2011;36:63-70.

36. Panda A, Garg I, Shah M. Children's preferences concerning ambiance of dental waiting rooms. Eur Arch Paediatr Dent. 2015 Feb;16(1):27-33.

37. Prado IM, Carcavalli L, Abreu LG, Serra-Negra IM, Paiva SM, Martins CC. Use of distraction techniques for the management of anxiety and fear in paediatric dental practice: A systematic review of randomized controlled trials. Int J Paediatr Dent. 2019 Sep;29(5):650-68. 